\title{
Pterocidin, a Cytotoxic Compound from the Endophytic Streptomyces hygroscopicus
}

\author{
Yasuhiro Igarashi, Shin-suke Miura, Tsuyoshi Fujita, Tamotsu Furumai
}

Received: September 13, 2005 / Accepted: February 20, 2006

(C) Japan Antibiotics Research Association

\begin{abstract}
A new cytotoxic compound, pterocidin, was isolated from the endophytic Streptomyces hygroscopicus TP-A0451, and the structure was determined on the basis of spectroscopic data. Pterocidin showed cytotoxicity against some human cancer cell lines with $\mathrm{IC}_{50}$ values of $2.9 \sim 7.1 \mu \mathrm{M}$.
\end{abstract}

Keywords pterocidin, Streptomyces, cytotoxic, $\delta$ lactone

Actinomycetes associated with plants are recognized as an emerging source of novel natural products [1 3]. We have previously reported the isolation of pteridic acids A and B with plant growth promoting activity from the endophytic Streptomyces hygroscopicus TP-A0451 [1]. This strain has been so far identified to produce structurally diverse secondary metabolites; an antifungal prenylated indole [2], a sulfonated linear polyene antibiotic with antifungal activity [3], galbonolides A and B [4, 5], elaiophylin [6] and its derivatives, and herbimycins [7] and their hydroquinone congeners. Our continuous search for bioactive compounds from the strain TP-A0451 led to the isolation of pterocidin (1), a new cytotoxic compound. We herein describe the isolation and structure elucidation of $\mathbf{1}$.

Ten liters of the culture broth of S. hygroscopicus TPA0451 were extracted with 1-butanol, and the extract was fractionated on a silica gel column and further subjected to
C-18 column chromatography to yield pterocidin (1, $11 \mathrm{mg}$ ) as pale yellow oil.

The molecular formula of $\mathbf{1}$ was established to be $\mathrm{C}_{23} \mathrm{H}_{34} \mathrm{O}_{6}$ based on ${ }^{13} \mathrm{C}$ NMR and HRFABMS $[\mathrm{m} / \mathrm{z}$ 429.2260, $(\mathrm{M}+\mathrm{Na})^{+}, \Delta+0.7 \mathrm{mmu}$ ]. IR absorption of $\mathbf{1}$ indicated the presence of hydroxyl $\left(3450 \mathrm{~cm}^{-1}\right)$ and $\alpha, \beta$ unsaturated lactone carbonyl $\left(1720 \mathrm{~cm}^{-1}\right)$ groups. The UV absorption $\left[\lambda_{\max }(\mathrm{MeOH}) 229(\varepsilon 22,900) \mathrm{nm}\right]$ of 1 was indicative of an $\alpha, \beta$-unsaturated carbonyl chromophore. The ${ }^{1} \mathrm{H}$ and ${ }^{13} \mathrm{C}$ NMR, DEPT, and HMQC spectra of $\mathbf{1}$ in $\mathrm{CDCl}_{3}$ (Table 1) revealed the presence of signals due to one carbonyl carbon, one oxygenated $s p^{2}$ quaternary carbon, nine $s p^{2}$ methines, four $s p^{3}$ methines adjacent to oxygen atoms, one $s p^{3}$ methine, two $s p^{3}$ methylenes, three methoxy groups, and two methyls. Since six out of 7 unsaturations were accounted for, 1 was inferred to possess one ring.

DQF-COSY spectrum revealed two ${ }^{1} \mathrm{H}-{ }^{1} \mathrm{H}$ connectivities from $\mathrm{H}-2$ to $\mathrm{H}-13$ branching $\mathrm{H}-22$ at $\mathrm{C}-12$ and from $\mathrm{H}-15$ to $\mathrm{H}-19$. The HMBC correlations for $\mathrm{H}-15 / \mathrm{C}-13$ and $\mathrm{H}-$ 15/C-14 suggested the connectivity between C-13 and C-

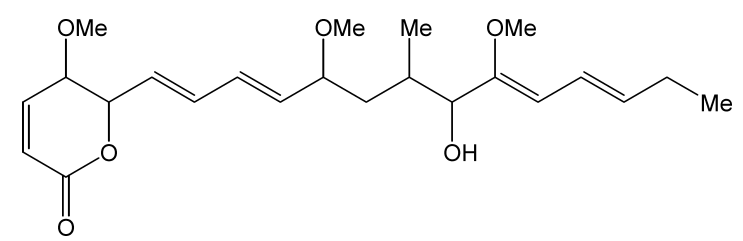

Fig. 1 Structure of pterocidin (1).
Y. Igarashi (Corresponding author), S. Miura, T. Furumai: Biotechnology Research Center, Toyama Prefectural University, 5180 Kurokawa, Kosugi, Toyama 939-0398, Japan, E-mail: yas@pu-toyama.ac.jp
T. Fujita: Suntory Institute for Bioorganic Research, 1-1-1 Wakayamadai, Shimamoto, Mishima, Osaka 618-8503, Japan 
Table 1 Physico-chemical properties of pterocidin

\begin{tabular}{ll}
\hline Appearance & Pale yellow oil \\
{$[\alpha]_{D}^{20}$} & $-27.7^{\circ}\left(c 0.46, \mathrm{CHCl}_{3}\right)$ \\
HRFAB-MS & \\
$\quad$ Found & $429.2260(\mathrm{M}+\mathrm{Na})^{+}$ \\
$\quad$ Calcd. & $429.2253\left(\right.$ for $\left.\mathrm{C}_{23} \mathrm{H}_{34} \mathrm{O}_{6} \mathrm{Na}\right)$ \\
Molecular formula & $\mathrm{C}_{23} \mathrm{H}_{34} \mathrm{O}_{6}$ \\
UV (MeOH) $\lambda_{\max } \mathrm{nm}(\varepsilon)$ & $229(22,900), 275(2,500)$ \\
IR (neat) $v_{\max } \mathrm{cm}^{-1}$ & 3450,1720 \\
\hline
\end{tabular}

Table 2 NMR assignment for pterocidin $\left(\mathrm{CDCl}_{3}\right)$

\begin{tabular}{|c|c|c|}
\hline Position & $\delta^{13} \mathrm{C}$ & $\delta^{1} \mathrm{H}$ (mult., $J$ in $\mathrm{Hz}$ ) \\
\hline 1 & 162.6 & \\
\hline 2 & 123.3 & $6.16(d d, 10.0,0.7)$ \\
\hline 3 & 143.1 & $6.94(d d, 10.0,4.4)$ \\
\hline 4 & 71.2 & $4.02(\mathrm{ddd}, 4.4,4.2,0.7)$ \\
\hline 5 & 79.8 & $4.98(\mathrm{ddd}, 6.8,4.2,1.0)$ \\
\hline 6 & 125.8 & $5.89(\mathrm{dd}, 15.4,6.8)$ \\
\hline 7 & 134.1 & $6.44(\mathrm{ddd}, 15.4,10.5,1.0)$ \\
\hline 8 & 131.4 & $6.24(\mathrm{dd}, 15.4,10.5)$ \\
\hline 9 & 135.9 & $5.61(\mathrm{dd}, 15.4,7.8)$ \\
\hline 10 & 79.7 & $3.73(\mathrm{~m})$ \\
\hline 11 & 39.6 & $1.60(\mathrm{~m}), 1.66(\mathrm{~m})$ \\
\hline 12 & 33.1 & $1.96(\mathrm{~m})$ \\
\hline 13 & 74.5 & $4.06(b r d, 3.4)$ \\
\hline 14 & 155.3 & \\
\hline 15 & 111.8 & $5.58(d, 11.0)$ \\
\hline 16 & 122.4 & $6.34(\mathrm{ddt}, 15.4,11.0,1.5)$ \\
\hline 17 & 134.8 & $5.67(\mathrm{dt}, 15.4,6.6)$ \\
\hline 18 & 26.0 & $2.10(\mathrm{~m})$ \\
\hline 19 & 13.7 & $1.02(t, 6.8)$ \\
\hline 20 & 57.2 & 3.43 (s) \\
\hline 21 & 56.3 & 3.27 (s) \\
\hline 22 & 13.6 & $0.89(d, 6.8)$ \\
\hline 23 & 60.0 & 3.70 (s) \\
\hline
\end{tabular}

14. The NOE between H-13 and H-15 suggested the Zconfiguration at $\mathrm{C}-14 / \mathrm{C}-15$. The coupling constants between H-6 and H-7 $(J=15.4 \mathrm{~Hz}), \mathrm{H}-8$ and $\mathrm{H}-9$ $(J=15.4 \mathrm{~Hz})$, and $\mathrm{H}-16$ and $\mathrm{H}-17(J=15.4 \mathrm{~Hz})$ indicated that the configurations at C-6/C-7, C-8/C-9, and C-16/C-17 are trans. HMBC correlations for H-20/C-4, H-21/C-10, and $\mathrm{H}-23 / \mathrm{C}-14$ confirmed the methoxy substituents at these carbons. The existence of $\alpha, \beta$-unsaturated $\delta$-lactone ring was indicated by the chemical shift of H-5 ( $\delta$ 4.98) implying the connectivity between $\mathrm{O}-5$ and the carbonyl $\mathrm{C}-1$ and the coupling constant for $\mathrm{H}-2 / \mathrm{H}-3(\mathrm{~J}=10 \mathrm{~Hz})$

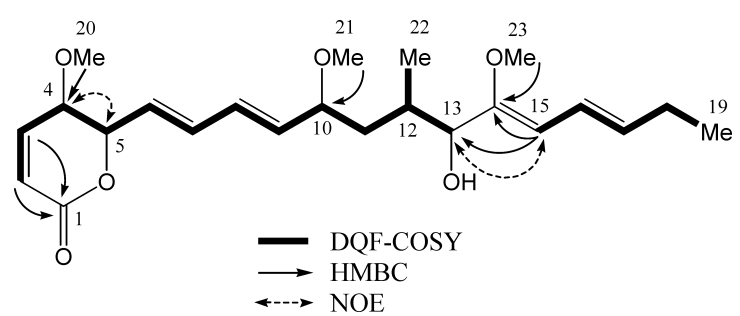

Fig. 2 Selected 2D NMR correlations and NOE observed for pterocidin (1).

that supports the cis-configuration for C-2/C-3. Thus, the structure of pterocidin was elucidated to be $\mathbf{1}$. As for the stereochemistry, the relative configuration at C-4/C-5 was suggested to be cis by the strong NOESY correlation between $\mathrm{H}-4$ and H-5. Absolute configuration of $\mathbf{1}$ is currently under investigation.

Pterocidin (1) is a new compound possessing an $\alpha, \beta$ unsaturated $\gamma$-oxygenated $\delta$-lactone at one end of the molecule with five chiral centers. Similar polyketidederived $\delta$-lactones have been isolated from actinomycetes [8 12] and marine sponges $[13,14]$ and many of them show antitumor activity. The structure of $\mathbf{1}$ is closely related to sultriecin [8], PD 113271 [9], and pironetin [10], antitumor compounds produced by Streptomyces species. Pterocidin (1) showed cytotoxicity against the cancer cell lines NCI-H522, OVCAR-3, SF539, and LOX-IMVI with $\mathrm{IC}_{50}$ values of $2.9,3.9,5.0$, and $7.1 \mu \mathrm{M}$, respectively, but no significant activity was exhibited against microorganisms.

\section{Experimental}

\section{General Experimental Procedures}

Optical rotation was recorded on a JASCO DIP-1030 polarimeter. The IR and UV spectra were taken on Shimadzu FT-IR300 and Hitachi U-3210 spectrophotometers, respectively. NMR experiments were performed on a JEOL JNM-LA400 NMR spectrometer with TMS as an internal standard. FAB mass spectra were obtained on a JEOL HX-110 spectrometer.

\section{Fermentation and Isolation}

Isolation and fermentation of the producing strain $S$. hygroscopicus TP-A0451 was previously described [1, 15]. In brief, strain TP-A0451 was cultivated in a liquid medium, and the cultured whole broth (10 liters) was extracted with 1-butanol (10 liters). The organic layer was concentrated in vacuo to yield crude solid $(33.7 \mathrm{~g})$. The solid was suspended in $\mathrm{CH}_{3} \mathrm{CN}$ and the soluble part was collected by filtration and evaporated to give dark brown oil 
$(6.6 \mathrm{~g})$. This was chromatographed over silica gel column $\left(\mathrm{CHCl}_{3}-\mathrm{MeOH}=100: 1 \sim 1: 1\right)$ and the fraction eluted with $\mathrm{CHCl}_{3}-\mathrm{MeOH}=20: 1$ was collected and evaporated to give crude material $(648 \mathrm{mg})$. It was further purified on C-18 column $(200 \times 40 \mathrm{~mm}$, i.d., ODS-AM 120-S50, YMC Co., Ltd.) with a stepwise gradient of $20 \sim 80 \% \mathrm{CH}_{3} \mathrm{CN}$ in $0.15 \% \mathrm{~K}_{2} \mathrm{HPO}_{4}$ buffer $(\mathrm{pH} 3.5)$. Fractions containing pterocidin (eluted with $60 \% \mathrm{CH}_{3} \mathrm{CN}$ in buffer) was evaporated in vacuo and the remaining aqueous solution was extracted with EtOAc. The organic layer was evaporated to dryness to yield pterocidin (11 mg).

\section{Cytotoxic Assay}

$\mathrm{IC}_{50}$ values of pterocidin against human cancer cell lines were determined in the same manner as described [16].

Acknowledgments We thank to Dr. T. Yamori at Cancer Chemotherapy Center, Japanese Foundation of Cancer Research for the evaluation of cytotoxicity of pterocidin.

\section{References}

1. Igarashi Y, Iida T, Yoshida R, Furumai T. Pteridic acids A and B, novel plant growth promoters with auxin-like activity from Streptomyces hygroscopicus TP-A0451. J Antibiot 55: 764-767 (2002)

2. Sasaki T, Igarashi Y, Ogawa M, Furumai T. Identification of 6-prenylindole as an antifungal metabolite of Streptomyces sp. TP-A0595 and synthesis and bioactivity of 6-substituted indoles. J Antibiot 55: 1009-1012 (2002)

3. Furumai T, Yamakawa T, Yoshida R, Igarashi Y. Clethramycin, a new inhibitor of pollen tube growth with antifungal activity from Streptomyces hygroscopicus TPA0623. I. Screening, taxonomy, fermentation, isolation and biological properties. J Antibiot 56: 700-704 (2003)

4. Achenbach H, Mühlenfeld A, Fauth U, Zähner $\mathrm{H}$. Galbonolides A and B-two new non-glycosidic antifungal macrolides from Streptomyces galbus. Tetrahedron Lett 26: 6167-6170 (1985)

5. Takatsu T, Nakayama H, Shimazu A, Furihata K, Ikeda K, Furihata K, Seto H, Otake N. Rustmicin, a new macrolide antibiotic active against wheat stem rust fungus. J Antibiot 38: 1806-1809 (1985)
6. Ley SV, Neuhaus D, Williams DJ. A conformational study of elaiophylin by X-ray chrystallography and difference ${ }^{1} \mathrm{H}$ NMR method; observation of a selective sign reversal of the nuclear Overhauser effect. Tetrahedron Lett 23: 1207-1210 (1982)

7. Shibata K, Satsumabayashi S, Nakagawa A, Ōmura S. The structure and cytocidal activity of herbimycin C. J Antibiot 39: 1630-1633 (1986)

8. Ohkuma H, Naruse N, Nishiyama Y, Tsuno T, Hoshino Y, Sawada Y, Konishi M, Oki T. Sultriecin, a new antifungal and antitumor antibiotic from Streptomyces roseiscleroticus. Production, isolation, structure and biological activity. J Antibiot 45: 1239-1249 (1992)

9. Hokanson GC, French JC. Novel antitumor agents CI-920, PD 113270, and PD 113271. 3. Structure determination. J Org Chem 50: 462-466 (1985)

10. Kobayashi S, Tsuchiya K, Harada T, Nishide M, Kurokawa T, Nakagawa T, Shimada N, Kobayashi K. Pironetin, a novel plant growth regulator produced by Streptomyces sp. NK10958. J Antibiot 47: 697-702 (1994)

11. Amemiya M, Someno T, Sawa R, Naganawa H, Ishizuka M, Takeuchi T. Cytostatin, a novel inhibitor of cell adhesion to components of extracellular matrix produced by Streptomyces sp. MJ654-NF4. II. Physico-chemical properties and structure determination. J Antibiot 47: 541-544 (1994)

12. Hamamoto T, Seto H, Beppu T. Leptomycins A and B, new antifungal antibiotics. II. Structure elucidation. J Antibiot 36: 646-650 (1983)

13. Kobayashi M, Higuchi K, Murakami N, Tajima H, Aoki S. Callystatin, a potent cytotoxic polyketide from the marine sponge, Callyspongia truncata. Tetrahedron Lett 38: 2859-2862 (1997)

14. Sirirah S, Tanaka J, Ohtani I, Ichiba T, Rachmat R, Ueda K, Usui $T$, Osada $H$, Higa $T$. Bitungolides $A \sim F$, new polyketides from the Indonesian sponge Theonella $\mathrm{cf}$. swinhoei. J Nat Prod 65: 1820-1823 (2002)

15. Igarashi Y, Iida T, Sasaki T, Saito N, Yoshida R, Furumai T. Isolation of actinomycetes from live plants and evaluation of antiphytopathogenic activity of their metabolites. Actinomycetol 16: 9-13 (2002)

16. Furumai $\mathrm{T}$, Takagi $\mathrm{K}$, Igarashi $\mathrm{Y}$, Saito $\mathrm{N}$, Oki $\mathrm{T}$. Arisostatins A and B, new members of tetrocarcin class of antibiotics from Micromonospora sp. TP-A0316. I. Taxonomy, fermentation, isolation and biological properties. J Antibiot 53: 227-232 (2000) 